\title{
Comparison of Hexane, Methanol, and Their Mixtures as Solvents for Microalgae Lipid Extraction by Hydrodynamic Cavitation
}

\section{Perbandingan Penggunaan Pelarut Heksana, Metanol dan Campurannya untuk Ekstraksi Lipid Mikroalga dengan Kavitasi Hidrodinamika}

\author{
Martomo Setyawan a,1,*, Siti Jamilatun ${ }^{\text {a,2 }}$, Muhammad Nufail Syafii a,3, Resyaldi Pratama ${ }^{\text {a,4 }}$ \\ ${ }^{a}$ Program Studi Teknik Kimia, Fakultas Teknologi Industri, Universitas Ahmad Dahlan, Jalan Ring Road Selatan, Tamanan, Bantul, 55166 \\ ${ }^{1}$ martomo@che.uad.ac.id*; ${ }^{2}$ sitijamilatun@che.uad.ac.id; ${ }^{3}$ nufail.trix11@gmail.com; ${ }^{4}$ resyaldipratama@gmail.com \\ * corresponding author
}

\section{ARTICLE INFO}

Article history

Received May 28, 2020

Revised October 21, 2020

Accepted January 14, 2020

Keywords

Biodiesel

Extraction

Hydrodynamic Cavitation

Microalgae Lipids

Solvent combination

\section{ABSTRACT}

The process of producing biodiesel from microalgae as an effort to solve energy problems is currently constrained by the negative energy balance, which requires more energy to produce than the heating value of biodiesel. The lipid extraction assisted by hydrodynamic cavitation requires less energy extraction than the heating value of biodiesel. The effort to increase the energy efficiency of the hydrodynamic cavitation extraction process is to find a solvent that has a low boiling point. This study aims to improve energy efficiency by using a solvent mixture of hexane and methanol, which has a low boiling point. The results showed that the methanol hexane mixture with a volume ratio of $4: 1$ gave the lowest mixture boiling point of $51.2{ }^{\circ} \mathrm{C}$ with a yield of $3.28 \% \mathrm{~g}$ lipid / $\mathrm{g}$ dry microalgae. The process runs at a temperature of $30{ }^{\circ} \mathrm{C}$ with a driving pressure of $5 \mathrm{~kg} / \mathrm{cm}^{2}$, with an extraction energy requirement of $2 \mathrm{~kJ} / \mathrm{g}$ of lipids. This process is feasible to be developed to produce biodiesel from microalgae with a positive energy balance.

This is an open access article under the CC-BY-SA license.

\section{Pendahuluan}

Meningkatnya permintaan energi dan berkurangnya sumber bahan bakar fosil sebagai sumber energi utama menimbulkan masalah energi. Masalah disebabkan karena bahan bakar fosil adalah sumber energi yang tidak dapat diperbarui [1]. Selain permasalahan energi, penggunaan bahan bakar fosil juga menimbulkan pemanasan global karena emisi gas rumah kaca seperti karbon dioksida. Salah satu alternatif untuk menyelesaikan permasalahan energi dan pemanasan global adalah dengan menggunakan bahan bakar yang dapat diperbarui [2]. Solusi ini tidak hanya akan menyelesaikan masalah energi tetapi juga masalah lingkungan karena dengan sumber energi terbarukan maka untuk menghasilkan sumber daya energi, sumber energi berupa tanaman membutuhkan karbondioksida untuk tumbuh. Karenanya, ia akan membentuk rantai karbon tertutup [3].

Masalah lain yang berpotensi muncul dengan penggunaan sumber energi terbarukan berupa minyak nabati adalah ketahanan pangan, karena untuk meningkatkan energi maka akan digunakan minyak sumber pangan sebagai sumber energi. Masalah ini dapat dihindari dengan memilih minyak nabati yang tidak dapat dimakan atau limbah biomassa sebagai sumber energi [4]. Beberapa penelitian untuk mencari sumber bahan bakar dari sumber bukan pangan dan limbah telah dilakukan oleh beberapa peneliti seperti, cabang buah kosong kelapa sawit yang telah diolah menjadi bio-oil 
[5], distilat asam lemak kelapa yang diolah menjadi biodiesel [6], produksi gas dari ampas tebu [7], produksi bio-oil dari limbah kayu, buah-buahan dan sayuran [8], bio-oil dari ampas mikroalga [9], biodiesel dari biji bukan bahan pangan seperti biji jarak dan biji pepaya [10] dan produksi energi dengan pengolahan termal atau biologis limbah organik [11]. Baru-baru ini, beberapa peneliti sedang menyelidiki produksi biodiesel generasi ketiga dari lipid mikroalga [4].

Mikroalga telah terbukti sebagai sumber energi potensial di masa depan dengan berbagai keuntungan yang menarik seperti produktivitas dan kandungan minyak yang lebih tinggi dibandingkan dengan tanaman energi lainnya. Keuntungan lain seperti kebutuhan air bersih yang lebih rendah dan dapat tumbuh pada lahan non produktif. Keunggulan-keunggulan ini meningkatkan minat para peneliti untuk mengolah mikroalga untuk pengembangan produk seperti biofuel. Mikroalga juga dapat tumbuh di air limbah industri pabrik kelapa sawit (POME) [12], hal ini merupakan potensi tekno-ekonomi yang tinggi [13]. Sedangkan keunggulan yang menarik adalah mikroalga tumbuh menggunakan karbon dioksida untuk fotosintesis, hal ini mengurangi efek pemanasan global. Nilai tambah lain dari menggunakan mikroalga sebagai sumber energi disamping kandungan minyaknya adalah menghasilkan bio-oil dari limbah biomassa mikroalga [9].

Beberapa studi tentang pembuatan biodiesel dari lipid mikroalga telah menyimpulkan bahwa proses tidak menguntungkan pada skala industri [14]. Salah satu masalah tersebut disebabkan oleh kebutuhan energi ekstraksi yang lebih tinggi dari panas pembakaran biodiesel itu sendiri. Kebutuhan energi untuk mengekstraksi lipid mikroalga secara mekanik telah dilaporkan sekitar 529 kJoule/gram mikroalga kering dan yang terendah adalah $3 \mathrm{kJoule/gram} \mathrm{mikroalga} \mathrm{kering,} \mathrm{sedangkan}$ nilai panas pembakaran biodiesel masing-masing hanya $42 \mathrm{kJoule} / \mathrm{gram}$ [15]. Jika diasumsikan persentase hasil lipid adalah $10 \%$ gram/gram, maka kebutuhan energi terendah akan sama dengan 30 kJoule/gram lipid. Perbandingan energi ini menunjukkan bahwa kebutuhan energi ekstraksi memainkan peran penting dalam proses pembuatan biodiesel dari mikroalga.

Kebanyakan proses ekstraksi konvensional lipid dari mikroalga memerlukan langkah dan waktu yang lama dan, membutuhkan energi. Oleh karena itu, kebutuhan akan proses ekstraksi yang cepat dengan energi rendah sangat penting. Salah satu metode ekstraksi yang membutuhkan energi jauh lebih rendah dibandingkan proses ekstraksi konvensional adalah kavitasi hidrodinamik. Teknik ini memberikan laju ekstraksi yang cepat [16] dan energi yang rendah. Kavitasi hidrodinamika terjadi karena adanya penurunan tekanan aliran di suatu titik pada sistem aliran tertutup. Penurunan tekanan ini disebabkan adanya peningkatan kecepatan aliran [17], oleh karena itu, teknik ini mudah untuk dikembangkan untuk skala besar [18]. Upaya peningkatan efisiensi energi dengan metode kavitasi hidrodinamika dilakukan dengan pemilihan pelarut yang memiliki titik didih rendah. Apabila tekanan lokal lebih rendah dari tekanan uap cairan maka mengakibatkan terjadinya penguapan. Semakin tinggi tekanan uap cairan maka semakin mudah cairan menguap atau dengan kata lain kavitasi yang terjadi akan semakin besar [19]. Dalam penelitian ini akan dilakukan perbandingan penggunaan metanol, heksana dan campuran keduanya untuk mendapatkan jenis dan perbandingan pelarut yang memberikan efisiensi energi yang tinggi.

\section{Metodologi Penelitian}

\subsection{Bahan Penelitian}

\section{1) Mikroalga}

Bahan mikroalga yang digunakan adalah Nannochloropsis sp. yang berasal dari Pusat Pembudidayaan Air Payau Situbondo. Mikroalga dibeli dalam keadaan kering.

\section{2) Pelarut}

Pelarut yang digunakan pada penelitian ini terdiri dari: metanol kualitas pro analisis dan teknis yang dibeli dari Toko CV. Aneka Kimia di Yogyakarta, heksana kualitas pro analisis dan teknis yang dibeli dari PT Brataco di Yogyakarta. Adapun sifat fisis dari pelarut yang digunakan dapat dibaca pada Tabel 1. 
Tabel 1. Sifat fisis pelarut yang digunakan

\begin{tabular}{ccc}
\hline Bahan & Heksana & Metanol \\
\hline Titik didih, ${ }^{\circ} \mathrm{C}$ & $68,7^{+}$ & $64,5^{+}$ \\
Densitas, $\mathrm{kg} / \mathrm{l}$ & $0,659^{+}$ & $0,792^{+}$ \\
Viskositas, mPa.s & $0,28^{*}$ & $0,544^{*}$ \\
Berat molekul, kg/kmol & $86,178^{+}$ & $32,042^{+}$ \\
Panas penguapan, kJ/kmol & $31.560^{+}$ & $37.340^{+}$ \\
\hline
\end{tabular}

* Sumber : Knothe \& Steidley [20]

+ Sumber : Poling et al. [21]

\subsection{Alat}

Percobaan ekstraksi dijalankan dalam serangkaian alat yang berupa ekstraktor kavitasi hidrodinamika yang bekerja secara batch. Rangkaian alat terdiri dari kompresor sebagai penekan udara penggerak, tabung sampel yang dilengkapi alat pengukur tekanan, termometer, pemanas, dan pengaduk udara. Tabung sampel disambung dengan pipa yang dilengkapi dengan alat pembangkit kavitasi dan penampung sampel. Selain alat ekstraksi digunakan pula alat pemisah padat-cair dan alat destilasi untuk memisahkan lipid dengan pelarut. Skema rangkaian alat terlihat pada Gambar 1. Campuran mikroalga dan pelarut bergerak karena dorongan tekanan udara dalam tempat sampel campuran mikroalga dan pelarut, sehingga terjadi aliran secara vertikal dari atas ke bawah dan membentuk kavitasi saat melintasi venturi sebagai pembangkit kavitasi.

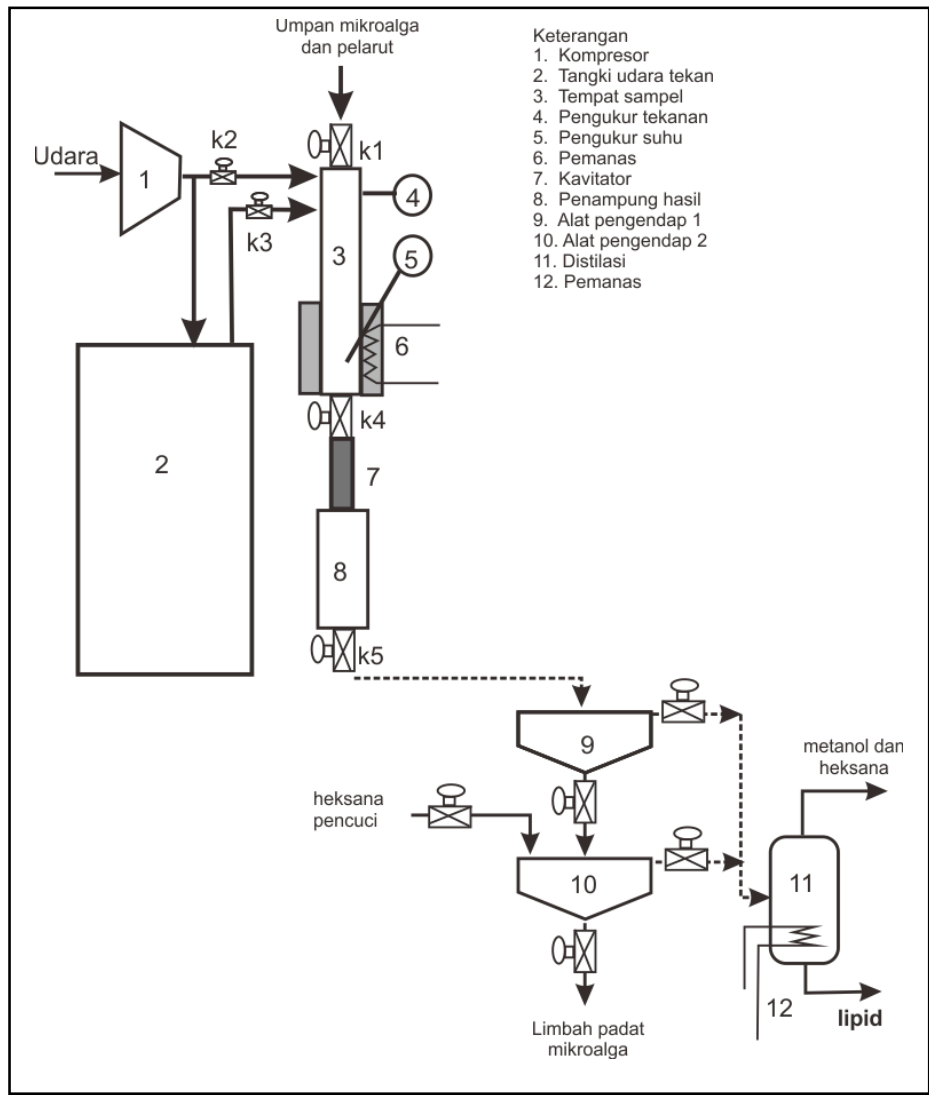

Gambar 1. Skema alat penelitian ekstraksi kavitasi hidrodinamika

\subsection{Cara Kerja}

\section{1) Karakterisasi mikroalga}

Karakterisasi mikroalga dilakukan untuk mengetahui kandungan lipid total dari sampel mikroalga. Cara karakterisasi dilakukan dengan ekstraksi 5 gram mikroalga kering dengan campuran pelarut metanol sebanyak $41 \mathrm{ml}$ dan n-heksana sebanyak $95 \mathrm{ml}$, selanjutnya diaduk dengan kecepatan pengadukan $1000 \mathrm{rpm}$ selama 2 jam. Setelah selesai pengadukan padatan dan pelarut dipisahkan dengan sentrifugasi dengan kecepatan 2500 rpm selama 10 menit. Proses ini dilakukan 3 kali untuk satu sampel mikroalga. Selanjutnya lipid yang diperoleh diuji dengan alat Gas Chromatography Mass Spectrometer untuk mengetahui komposisi kandungan asam lemaknya. 
2) Karakterisasi pelarut

Karakterisasi pelarut dilakukan untuk mengetahui titik didih pelarut dan campuran pelarut. karakterisasi pelarut dilakukan dengan menguji titik didih dari heksana murni, metanol murni dan campuran dengan komposisi berat heksana dibanding metanol sebagai berikut 1:9, 1:4, 2:3, 1:1, 3:2, 4:1 dan 9:1. Pelarut dan campuran pelarut dipanaskan sampai mendidih dan dicatat awal titik didihnya pada tekanan atmosferis.

\section{3) Ekstraksi kavitasi hidrodinamik}

Percobaan ekstraksi kavitasi hidrodinamik dilakukan dengan kondisi operasi pada suhu $30{ }^{\circ} \mathrm{C}$, tekanan pendorong $5 \mathrm{~kg} / \mathrm{cm}^{2}$ dan konsentrasi padat $7 \%$ gram $/ \mathrm{mL}$. Mikroalga dan pelarut dimasukkan ke dalam ruang sampel dan kemudian dialirkan melalui venturi dengan pendorong tekanan. Setelah ekstraksi selesai, fase cair dan fase padat dipisahkan menggunakan proses sentrifugasi. Untuk memastikan semua lipid yang diekstraksi dari mikroalga terambil, maka dilakukan pencucian terhadap padatan mikroalga, padatan dicuci dengan metanol dan heksana, selanjutnya larutan hasil pencucian ditambahkan ke larutan hasil sentrifugasi. Lipid yang terlarut dalam pelarut diambil dengan menguapkan pelarut. Penguapan pelarut dilakukan sehingga diperoleh lipid sebagai residu dengan berat konstan dan selanjutnya ditimbang dan dicatat sebagai $\mathrm{w}_{1}$. Setelah residu ditimbang, untuk mendapatkan massa lipid bebas dari padatan, pada langkah selanjutnya residu dicuci dengan $5 \mathrm{ml}$ heksana yang dilakukan sebanyak tiga kali pencucian, selanjutnya padatan yang tersisa dikeringkan sampai berat konstan dan dicatat sebagai $\mathrm{w}_{2}$. Berat lipid yang terekstrak adalah berat residu $\left(\mathrm{w}_{1}\right)$ dikurangi padatan yang tertinggal saat pencuci residu $\left(\mathrm{w}_{2}\right)$. Kadar lipid yang terekstrak dihitung dengan rumus kadar lipid pada persamaan (1).

$$
\text { Kadar lipid }=\frac{\left(w_{1}-w_{2}\right)}{\text { berat mikroalga kering }} \times 100 \%
$$

\section{Hasil dan Pembahasan}

\subsection{Karakterisasi Kandungan Lipid}

Hasil percobaan pengujian kandungan lipid total, didapat kandungan lipid total dari Nannochloropsis sp adalah 14,48\% dari berat kering. Hasil pengujian ini masuk dalam kisaran kandungan lipid Nannochloropsis sp pada umumnya sebesar $12-53 \%$ [2]. Komponen kandungan lipid yang diperoleh dianalisis dengan GCMS diperoleh hasil yang disajikan pada Gambar 2.

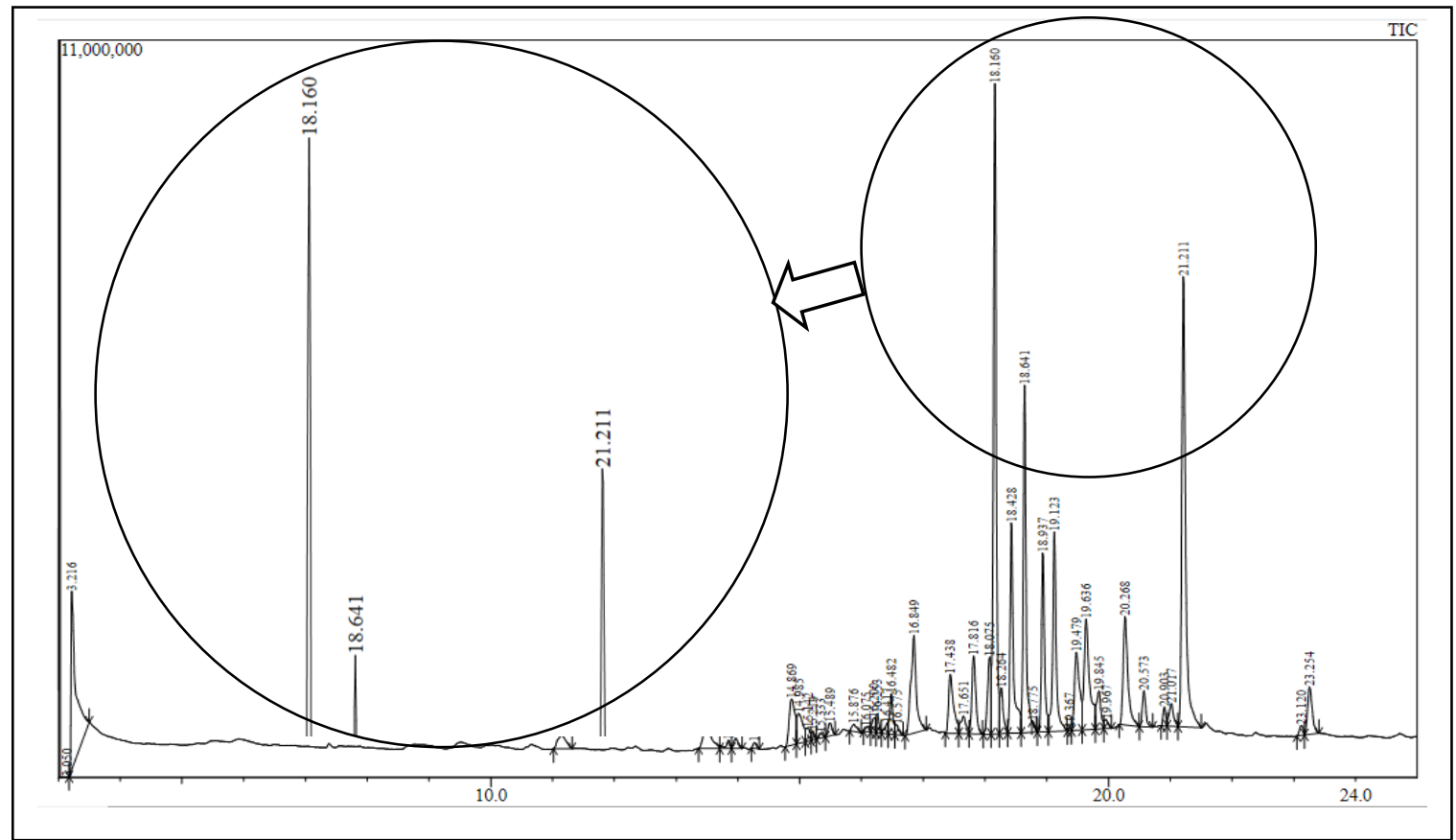

Gambar 2. Hasil analisis lipid dengan GCMS dengan 3 puncak tertinggi pada t 18,160; 18,641; dan 21,211 menit 
Dari hasil analisis dapat diketahui bahwa lipid terdiri dari 4 jenis senyawa yang dominan, yaitu Palmitic acid (C16:0), Palmitoleic acid (C16:1), Arachidonic acid (C20:4) dan Eicosapentaenoic acid (C20:5). Asam lemak dalam lipid mikroalga 90\%-98\% berat terdiri dari asam lemak trigliserida sehingga berpotensi sebagai bahan baku biodiesel, komponen lain mono dan digliserida jumlahnya sedikit, sedangkan asam lemak bebas berkisar 1\%-5\% [2].

Proses pembuatan biodiesel dari trigliserida melalui reaksi transesterifikasi yang terdiri dari beberapa langkah. Langkah tersebut meliputi konversi trigliserida menjadi digliserida, digliserida menjadi monogliserida dan selanjutnya monogliserida berubah menjadi ester (biodiesel) dan gliserol. Umumnya reaksi transesterifikasi melibatkan alkohol rantai pendek seperti metanol dan katalis basa seperti $\mathrm{NaOH}$ atau $\mathrm{KOH}$.

\subsection{Karakterisasi Pelarut}

Pemakaian pelarut yang tepat mempengaruhi efisiensi proses ekstraksi lipid dari mikroalga. Kandungan lipid yang terdiri dari trigliserida dan asam lemak bebas dapat larut dalam pelarut organik. Pelarut organik masuk ke dalam badan mikroalga dan membentuk komplek organo lipid yang akan keluar dari badan mikroalga karena perbedaan konsentrasi [22]. Pelarut organik dapat berupa pelarut organik polar dan non polar.

Pelarut organik non polar dapat memecah membran-protein-lipid pada mikroalga sedangkan pelarut organik polar dapat memecah protein-lipid, mekanisme pengambilan lipid melalui 5 langkah yaitu penetrasi pelarut organik melalui membran sel, interaksi pelarut organik dengan lipid kompleks, selama berinteraksi pelarut organik non-polar mengelilingi lipid kompleks dan membentuk ikatan van der Waals dengan lipid netral dalam kompleks, sedangkan pelarut organik membentuk ikatan hidrogen dengan lipid polar dalam kompleks. Ikatan hidrogen ini cukup kuat untuk mengganti gabungan lipid-protein yang mengikat lipid kompleks dengan membran sel. Tahap ketiga terbentuknya pelarut-lipid kompleks dan lepas dari membran sel. Selanjutnya terjadi difusi pelarut-lipid kompleks keluar membran sel. Terakhir, tercampurnya campuran pelarut-lipid kompleks dengan badan pelarut di luar mikroalga [23].

Pelarut yang digunakan dalam penelitian ini terdiri dari metanol, heksana, dan campuran keduanya. Metanol merupakan salah satu pelarut organik polar dan heksana adalah termasuk pelarut organik non polar. Pemilihan pelarut untuk ekstraksi lipid dengan kavitasi hidrodinamika selain kemampuan melarutkan lipid juga dipertimbangkan kemudahan menguap, karena kunci ekstraksi dengan kavitasi hidrodinamika adalah terbentuknya kavitasi karena penguapan pelarut dengan penurunan tekanan cairan dan mengembun kembali ketika tekanan kembali normal [16]. Metanol dan heksana memiliki titik didih 64,5 dan $68,7^{\circ} \mathrm{C}$, campuran metanol dan heksana membentuk campuran yang tidak saling campur karena metanol bersifat polar sedangkan heksana non polar. Titik didih campuran heksana dan metanol pada berbagai perbandingan volume dapat diketahui dari percobaan, nilai titik didih campuran dalam berbagai perbandingan heksana dan metanol terlihat pada Gambar 3.

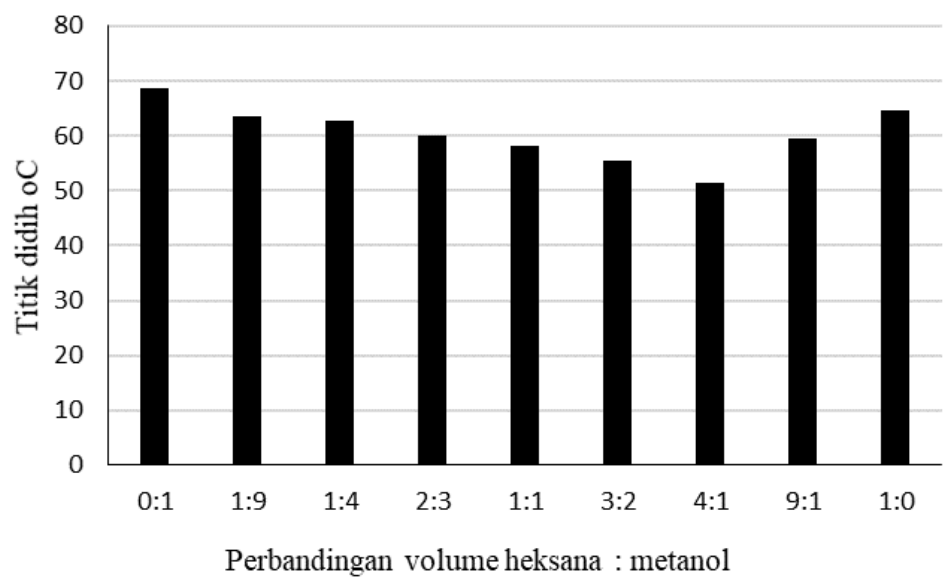

Gambar 3. Titik didih berbagai perbandingan volume heksana dan metanol 
Dari Gambar 3 terlihat titik didih campuran heksana metanol lebih rendah dibandingkan dengan titik didih metanol dan heksana murni, dan perbandingan terendah pada percobaan ini diperoleh pada perbandingan heksana metanol 4:1, sehingga penggunaan campuran kedua pelarut ini pada perbandingan volume heksana metanol 4:1 sangat baik untuk ekstraksi lipid dengan kavitasi hidrodinamika, karena akan menimbulkan kavitasi yang cukup besar. Kavitasi yang terjadi dapat diukur dengan bilangan kavitasi, yaitu besaran yang tidak berdimensi yang merupakan fungsi dari tekanan pendorong, tekanan uap, densitas fluida, dan kecepatan alir fluida yang dirumuskan dalam persamaan (2).

$$
C_{v}=\frac{p_{2}-p_{v}}{\frac{1}{2} \rho v^{2}}
$$

$\mathrm{C}_{\mathrm{v}}$ adalah bilangan kavitasi, $\mathrm{P}_{2}$ adalah tekanan awal fluida, $\mathrm{P}_{\mathrm{v}}$ adalah tekanan uap fluida, dan $\mathrm{v}$ adalah kecepatan fluida dalam saluran sempit. Untuk aliran dalam pipa maka bilangan kavitasi sebesar 1,5 sudah menimbulkan kavitasi. Semakin kecil bilangan kavitasi maka kavitasi yang terjadi semakin besar [19]. Pemakaian campuran heksana metanol 4:1 v/v memiliki tekanan uap 0,43 $\mathrm{kg} / \mathrm{cm}^{2}$, dengan tekanan pendorong $5 \mathrm{~kg} / \mathrm{cm}^{2}$ maka bilangan kavitasi terhitung sebesar 0,109 . Nilai bilangan kavitasi ini jauh lebih kecil dibandingkan nilai bilangan kavitasi saat terbentuk kavitasi, sehingga kavitasi yang terjadi pada sistem cukup besar.

\subsection{Ekstraksi Lipid Dengan Gabungan Pelarut Heksana dan Metanol}

\section{1) Menggunakan ekstraksi konvensional}

Dalam percobaan ini dilakukan percobaan ekstraksi dengan kombinasi pelarut heksana metanol secara konvensional dengan pengadukan $1000 \mathrm{rpm}$ selama 2 jam, dan hasil percobaan dapat dilihat pada Gambar 4.

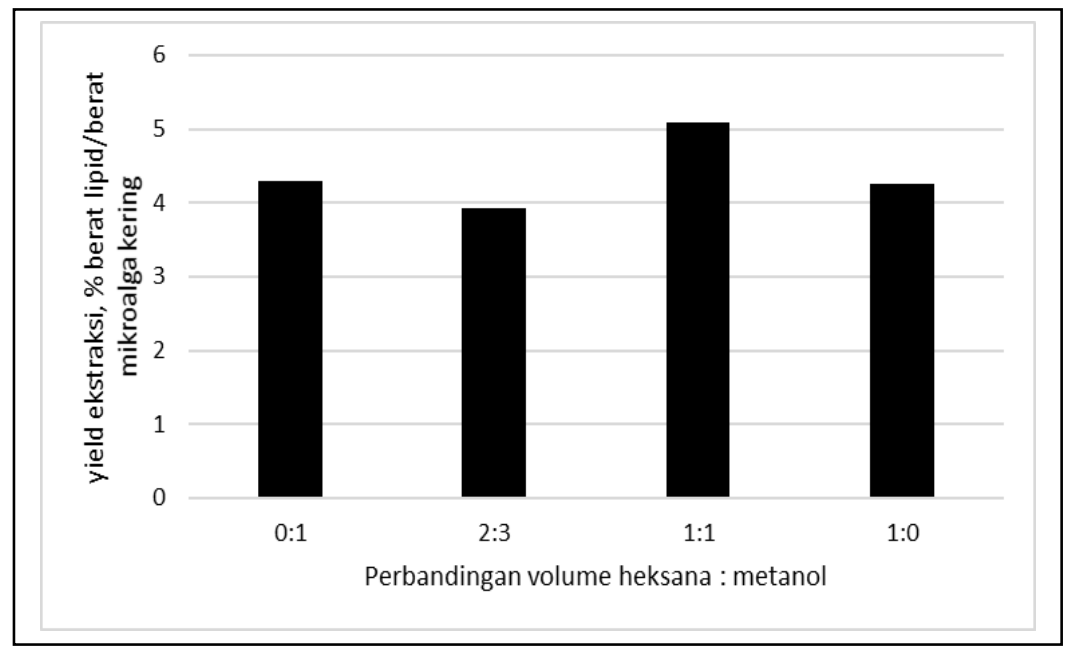

Gambar 4. Yield esktraksi konvensional selama 2 jam pada berbagai perbandingan volume pelarut

Dari Gambar 4 terlihat bahwa hasil yield rata-rata untuk ekstraksi konvensional dengan berbagai perbandingan heksana dan metanol adalah $4,39 \%$ berat lipid/berat mikroalga kering dengan waktu ekstraksi selama 2 jam. Hasil terbanyak diperoleh dengan perbandingan pelarut heksana banding metanol 1:1, dengan yield sebesar 5,08\% berat lipid/berat mikroalga kering. Dengan data berat mikroalga kering sebesar 7 gram dan diperoleh berat lipid sebesar 0,355 gram untuk 2 jam proses, dengan asumsi grafik yield terhadap waktu adalah linier [25] maka kecepatan ekstraksi dengan ekstraksi konvensional adalah 0,00296 gram/menit.

\section{2) Ekstraksi kavitasi hidrodinamika}

Ekstraksi lipid dengan bantuan pemecahan sel dari tekanan kejut kavitasi merupakan salah satu teknik ekstraksi yang sangat baik untuk ekstraksi lipid dari mikroalga. Ekstraksi ini terjadi karena adanya perusakan dinding sel karena tekanan kejut kavitasi. Tekanan kejut kavitasi terjadi karena mengembunnya uap pelarut menjadi cair kembali. Peristiwa pengembunan ini akan menyebabkan pengurangan volume, karena volume fase gas untuk satu satuan massa senyawa lebih besar dibandingkan volume cairnya. Besarnya tekanan kejut bisa mencapai 1.250 bar saat volume molar berkurang menjadi $1 / 20$ kali [19]. 
Dalam penerapan kavitasi untuk ekstraksi lipid maka jumlah energi yang diperlukan jauh lebih kecil dibandingkan dengan ekstraksi konvensional atau ekstraksi dengan pemecahan sel metode lain seperti microwave, ultrasonic, high pressure homogenizer [15], [24]. Hasil percobaan ekstraksi dengan kavitasi hidrodinamika dapat dilihat pada Gambar 5, percobaan dengan ekstraksi kavitasi hidrodinamika dilakukan dalam sekali aliran dengan waktu total 1 menit.

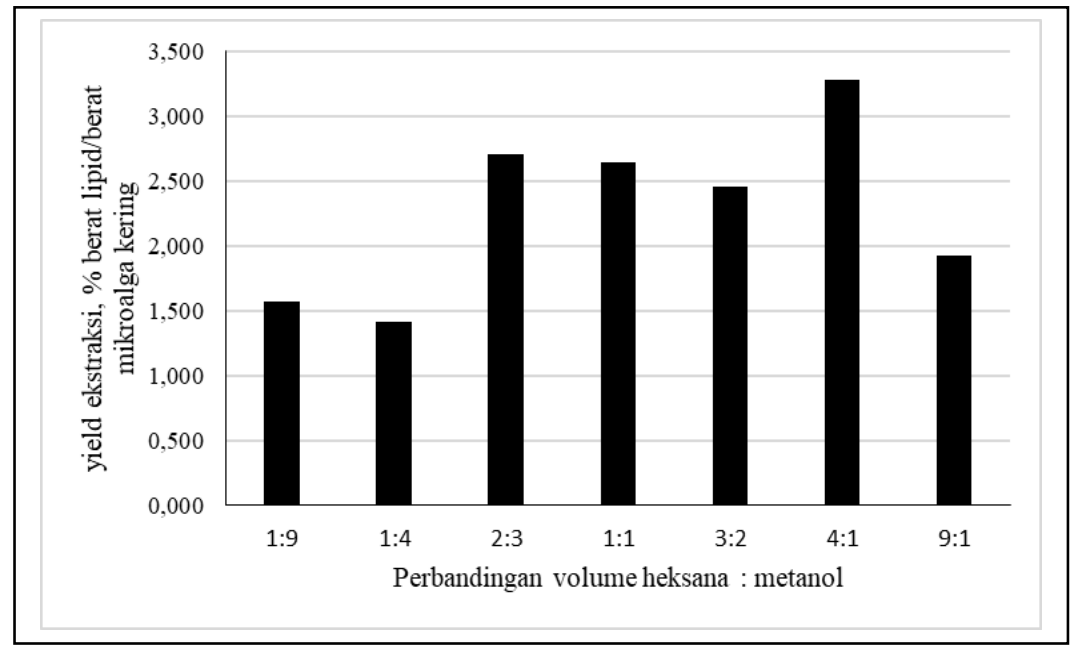

Gambar 5. Yield esktraksi kavitasi hidrodinamika

Dari Gambar 5 terlihat bahwa penggunaan perbandingan volume heksana dan metanol yang berbeda memberikan yield ekstraksi yang berbeda, hasil tertinggi pada perbandingan volume heksana metanol 4:1 sebesar 3,28\% berat lipid/berat kering mikroalga, yield tertinggi ini diperoleh pada titik didih campuran terendah yaitu $51,5{ }^{\circ} \mathrm{C}$. Hasil ini menunjukkan bahwa sifat fisis titik didih pelarut memiliki pengaruh yang dominan terhadap yield ekstraksi dengan kavitasi hidrodinamika. Energi yang dibutuhkan untuk melakukan ekstraksi sebesar 720 Joule apabila dihitung perberat lipid yang diperoleh maka energi yang diperlukan $2 \mathrm{~kJ}$ Joule/gram lipid. Jumlah energi yang diperlukan ini jauh lebih kecil dibandingkan panas pembakaran biodiesel. Besarnya panas pembakaran tinggi (HHV) dan rendah (LHV) dari biodiesel bermacam-macam tergantung jenis asam lemak penyusunnya, untuk HHV biodiesel berkisar antara 39,5 sampai 41 kJoule/gram sedangkan LHV berkisar 36,5 sampai 39 kJoule/gram [26], sehingga proses ini sangat menjanjikan untuk dikembangkan untuk produksi biodiesel dari mikroalga.

\section{3) Perbandingan kecepatan esktraksi konvensional dan kavitasi hidrodinamika dengan pelarut} campuran heksana metanol 1:1

Kecepatan ekstraksi dengan metode konvensional pengadukan $1000 \mathrm{rpm}$ selama 2 jam dengan pelarut campuran heksana metanol 1:1 adalah 0,00296 gram/menit. Perhitungan ini dilakukan dengan mengambil kecepatan ekstraksi selama 2 jam relatif konstan [25]. Sedangkan dengan kavitasi hidrodinamika dengan perbandingan pelarut yang sama untuk 1 menit proses diperoleh 0,229 gram lipid, maka kecepatan ekstraksi adalah 0,229 gram/menit. Kecepatan ekstraksi kavitasi hidrodinamika menurun seiring dengan ulangan proses, pada ulangan ekstraksi kedua sampai ke sepuluh kecepatan rata-rata ekstraksi adalah 0,044 gram/menit [25]. Sehingga untuk mencapai yield yang sama dengan esktraksi konvensional selama 2 jam, dengan ekstraksi kavitasi hidrodinamika diperlukan 4 kali ulangan atau 4 menit waktu ekstraksi. Perbandingan ini menunjukkan ekstraksi dengan kavitasi hidrodinamika memberikan kecepatan yang jauh lebih cepat dibandingkan kecepatan ekstraksi konvensional. Hal ini disebabkan karena adanya perusakan dinding mikroalga oleh tekanan kejut kavitasi [18].

\section{Kesimpulan}

Ekstraksi lipid dengan kavitasi hidrodinamika merupakan proses ekstraksi yang lebih cepat dibandingkan dengan proses ekstraksi konvensional. Pemilihan pelarut dalam ekstraksi kavitasi hidrodinamika didasarkan kepada titik didih pelarut, penggunaan campuran pelarut heksana dan metanol memberikan hasil yang maksimal pada perbandingan volume heksana metanol 4:1 saat campuran memiliki titik didih yang minimal. Dari hasil penelitian ekstraksi lipid dari mikroalga ini, 
menjanjikan untuk dikembangkan untuk membuat bahan bakar alternatif biodiesel dari mikroalga karena energi ekstraksi tiap berat lipid jauh lebih kecil dibandingkan panas pembakaran biodiesel.

\section{Ucapan Terima Kasih}

Ucapan terima kasih kami ucapkan kepada Universitas Ahmad Dahlan Yogyakarta yang telah memberikan dana hibah penelitian skim hibah bersaing melalui Lembaga Penelitian dan Pengabdian kepada Masyarakat dan fasilitas penelitian di Laboratorium.

\section{Daftar Pustaka}

[1] Y. S. Pradana, H. Sudibyo, E. A. Suyono, Indarto, and A. Budiman, "Oil algae extraction of selected microalgae species grown in monoculture and mixed cultures for biodiesel production," Energy Procedia, vol. 105, pp. 277-282, 2017.

[2] T. M. Mata, A. A. Martins, and N. S. Caetano, "Microalgae for biodiesel production and other applications: A review," Renew. Sustain. Energy Rev., vol. 14, no. 1, pp. 217-232, 2010.

[3] J. P. Maity, J. Bundschuh, C. Y. Chen, and P. Bhattacharya, "Microalgae for third generation biofuel production, mitigation of greenhouse gas emissions and wastewater treatment: Present and future perspectives - A mini review," Energy, vol. 78, pp. 104-113, 2014.

[4] T. Suganya, M. Varman, H. H. Masjuki, and S. Renganathan, "Macroalgae and microalgae as a potential source for commercial applications along with biofuels production: A biorefinery approach," Renew. Sustain. Energy Rev., vol. 55, pp. 909-941, 2016.

[5] Sunarno, Rochmadi, P. Mulyono, M. Aziz, and A. Budiman, "Kinetic study of catalytic cracking of biooil over silica-alumina catalyst," BioResources, vol. 13, no. 1, pp. 1917-1929, 2018.

[6] D. R. Sawitri, Sutijan, and A. Budiman, "Kinetics study of free fatty acids esterification for biodiesel production from palm fatty acid distillate catalysed by sulphated zirconia," ARPN J. Eng. Appl. Sci., vol. 11, no. 16, pp. 9951-9957, 2016.

[7] Daniyanto, Sutijan, Deendarlianto, and A. Budiman, "Reaction kinetic of pyrolysis in mechanism of pyrolysis gasification process of dry torrified sugarcane bagasse," ARPN J. Eng. Appl. Sci., vol. 11, no. 16, pp. 9974-9980, 2016.

[8] D. R. Wicakso, M. Hidayat, and R. B. Cahyono, "Effect of temperature on catalytic decomposition of tar using Indonesian iron ore as catalyst," Int. J. Renew. Energy Res., vol. 8, no. 1, 2018.

[9] S. Jamilatun, A. Budiman, Budhijanto, and Rochmadi, "Non-catalytic slow pyrolysis of Spirulina Platensis residue for production of liquid biofuel," Int. J. Renew. ENERGY Res. S. Jamilatun al, vol. 7, no. 4, 2017.

[10]R. D. Kusumaningtyas, I. N. Aji, H. Hadiyanto, and A. Budiman, "Application of tin (II) chloride catalyst for high FFA Jatropha oil esterification in continuous reactive distillation column," Bull. Chem. React. Eng. Catal., vol. 11, no. 1, p. 66, 2016.

[11] M. Maisarah, C. P. C. Bong, W. Shin, and J. Shiun, "Review on the Suitability of Waste for Appropriate Waste-to- Energy Technology,” vol. 63, pp. 187-192, 2018.

[12]H. Kamyab, S. Chelliapan, and M. Fadhil, "Isolate New Microalgal Strain for Biodiesel Production and Using FTIR Spectroscopy for Assessment of Pollutant Removal from Palm Oil Mill Effluent ( POME )," vol. 63, pp. 91-96, 2018.

[13]N. Nabila, A. Hamid, and J. S. Lim, "Techno-economic Assessment of an Integrated Algae-based Biorefinery with Palm Oil Mill," vol. 63, no. 2014, pp. 169-174, 2018.

[14]E. Suali and R. Sarbatly, "Conversion of microalgae to biofuel," Renew. Sustain. Energy Rev., vol. 16, no. 6, pp. 4316-4342, 2012.

[15] A. K. Lee, D. M. Lewis, and P. J. Ashman, "Microalgal cell disruption by hydrodynamic cavitation for the production of biofuels," J. Appl. Phycol., vol. 27, no. 5, pp. 1881-1889, 2015.

[16] M. Setyawan, A. Budİman, P. Mulyono, and Sutijan, "Optimum extraction of algae-oil from microalgae using hydrodynamic cavitation," Int. J. Renew. Energy Res., vol. 8, no. 1, 2018. 
[17]A. K. Lee, D. M. Lewis, and P. J. Ashman, "Disruption of microalgal cells for the extraction of lipids for biofuels: Processes and specific energy requirements," Biomass and Bioenergy, vol. 46, pp. 89-101, 2012.

[18]I. Lee and J. I. Han, "Simultaneous treatment (cell disruption and lipid extraction) of wet microalgae using hydrodynamic cavitation for enhancing the lipid yield," Bioresour. Technol., vol. 186, pp. 246$251,2015$.

[19] J.-P. Franc and J.-M. Michel, Fundamentals of Cavitation. New York: Kluwer Academic Publishers, 2005.

[20]G. Knothe and K. R. Steidley, "Kinematic viscosity of biodiesel fuel components and related compounds. Influence of compound structure and comparison to petrodiesel fuel components," Fuel, vol. 84, no. 9, pp. 1059-1065, 2005.

[21]B. E. Poling, G. H. Thomson, D. G. Friend, R. L. Rowley, and W. V. Wilding, "Section 2: Physical and Chemical Data," in Perry's Chemical Engineers' Handbook, 2007, pp. 1-517.

[22]F. Yang, W. Xiang, X. Sun, H. Wu, T. Li, and L. Long, "A novel lipid extraction method from wet microalga Picochlorum sp. at room temperature,” Mar. Drugs, vol. 12, no. 3, pp. 1258-1270, 2014.

[23]R. Halim, M. K. Danquah, and P. A. Webley, "Extraction of oil from microalgae for biodiesel production: A review," Biotechnol. Adv., vol. 30, no. 3, pp. 709-732, 2012.

[24] N. Grimi, A. Dubois, L. Marchal, S. Jubeau, N. I. Lebovka, and E. Vorobiev, "Selective extraction from microalgae Nannochloropsis sp. using different methods of cell disruption," Bioresour. Technol., vol. 153, pp. 254-259, 2014.

[25] M. Setyawan, P. Mulyono, Sutijan, and A. Budiman, "Comparison of Nannochloropsis sp . cells disruption between hydrodynamic cavitation and conventional extraction," in MATEC Web of Conferences, 2018, vol. 01023, pp. 1-5.

[26]E. G. Giakoumis and C. K. Sarakatsanis, "Estimation of biodiesel cetane number, density, kinematic viscosity and heating values from its fatty acid weight composition," Fuel, vol. 222, no. March, pp. 574$585,2018$. 